\title{
Familial LCAT deficiency
}

INSERM

\section{Source}

INSERM. (1999). Orphanet: an online rare disease and orphan drug data base. Familial LCAT deficiency. ORPHA:79293

Familial LCAT (lecithin-cholesterol acyltransferase) deficiency (FLD) is a form of lecithincholesterol acyltransferase deficiency (LCAT; see this term) characterized clinically by corneal opacities, hemolytic anemia, and renal failure, and biochemically by severely decreased HDL cholesterol and complete deficiency of the LCAT enzyme. 